\title{
Fukačovy výzkumy v oblasti staré hudby jako inspirace pro dnešek
}

\section{Jiří Fukač's Ancient Music Research as an Inspiration for Today}

\author{
Jana Perutková / perutkov@phil.muni.cz \\ Department of Musicology, Faculty of Arts, Masaryk University, Brno, CZ
}

\begin{abstract}
The main goal of this study is to point out the importance of Ancient Music research by Jirí Fukač, the former musicologist at Masaryk University in Brno. The so called Ancient Music was Fukač's main research topic. Beside other things, his lifelong interest was proven by establishment of a new subject "Theory and Practice of Ancient Music" to study at the Department of Musicology, Faculty of Arts, Masaryk University in 1991.

Fukač's two volumes diploma theses Křižovnický hudební inventář I-II (The Knights of the Cross with the Red Star Inventory I-II) from 1959 was appreciated as a remarkable and inspiring artistic work soon after it had been defended. Later, the particular findings from The Knights of the Cross with the Red Star Music Inventory were subjects of Fukač's many other texts.

Methodological research of music processes within Czech Lands in the Baroque period and some related questions were other areas of Jiři Fukač's exploration. In his papers dedicated to research of Moravia in modern history, Fukač appealed for complex perception of Moravia as a geographical, demographical, ethnic, political-historical and cultural-historical phenomenon. He repeatedly turned his interest to the music performed in Mannheim in the 2 nd half of the 18th century; just as to court music ensembles and migration lines problems. In 1996 his great extensive essay Tschechische Musikinventare: Zur Frage der komplexen Bearbeitung historischer Musikverzeichnisse was published. The topic of this paper is a methodology of research in the Music inventories. The outcome of Fukač's research in years 1961-1965 was an imposing experiment to document all preserved historical Music inventories in Czech lands. This attempt set the ground as well as methodological inspiration for ongoing project Hudební inventáře raného novověku $v$ českých zemích (Music inventories of modern history within Czech lands) at Department of Musicology, Faculty of Arts, Masaryk University.
\end{abstract}

\section{Keywords}

Jiři Fukač, ancient music, The Knights of the Cross with the Red Star, Moravia, Mannheim, court music ensembles, music inventories 
Cílem této studie je nejen poukázat na Fukačovy výzkumy týkající se tzv. staré hudby, ale také do určité míry polemizovat s nepsaným názorem, že se tento muzikolog věnoval bádání v této oblasti pouze na počátku své vědecké kariéry a později se již zaměřoval na jiné oblasti historické i systematické hudební vědy. $\mathrm{O}$ tom, že stará hudba byla předmětem jeho celoživotního zájmu, ostatně svědčí nejen následující řádky, ale také skutečnost, že v r. 1991 prosadil na Ústavu hudební vědy FF MU, který tehdy vedl, otevření nového studijního oboru Teorie a provozovací praxe staré hudby. ${ }^{1}$ Tento obor je i přes nárůst zájmu o historickou interpretaci na JAMU a AMU jediným v ČR, který důsledně spojuje teoretické i praktické aspekty provozování staré hudby.

V době univerzitních studií Jiřího Fukače byla brněnská katedra pod zásadním vlivem spisů Vladimíra Helferta, které ostatně mají velký význam i pro dnešní dobu. V oblasti tzv. staré hudby se jednalo především o Helfertovy monografie týkající se Jiřího Antonína Bendy a zvláště pak hudební kultury v Jaroměřicích. ${ }^{2} \mathrm{~V}$ Helfertových šlépějích na tehdejší brněnské muzikologické katedře kráčel Jan Racek, a to např́iklad v pracích Slohové problémy italské monodie (Praha-Brno 1938, německy v r. 1965) nebo Duch českého hudebniho baroka (Brno 1940). ${ }^{3}$ Méně nápadné, zato však velmi dobře pramenně ukotvené byly též studie Bohumíra Štědroně zaměřené na oblast 18. století (byly věnovány jeho rodnému Vyškovsku, zemským trubačům, klášterní hudbě ad.). Výzkumem některých moravských pramenů k hudbě 17. a 18. století se v době Fukačových studií začala na vysoké úrovni zabývat rovněž Theodora Straková, o deset let mladší než Racek a Štědroň. Problematikou starších slohových epoch se zaobírali i Fukačovi generační i mladší univerzitní kolegové Rudolf Pečman a Miloš Štědroň. Heuristice daného období se pak především věnoval a dodnes neúnavně věnuje Jiří Sehnal, mimo jiné dlouholetý vedoucí hudebního oddělení Moravského zemského muzea.

Pozoruhodnou a inspirativní se stala už Fukačova dvousvazková diplomová práce Kř žovnický hudebni inventář I-II. Na jejím základě získal v r. 1959 titul promovaný historik a později i hodnost doktora filozofie. $\mathrm{V}$ této práci je velmi podrobně a fundovaně pojednán důležitý pramen, kterým je rukopisný inventář pražské sbírky křižovníků, pocházející z let 1737/1738 (s doplňky do roku 1756). Fukač jej objevil v klášteře v Hradišti u Znojma v r. 1956. Provedl edici, podrobný popis a analýzu tohoto pramene. Pro ilustraci náročnosti této práce uved'me, že inventář obsahuje přibližně tři a půl tisíce položek.

1 Na vzniku oboru se dále podíleli Andreas Kröper-Hoffmann, Petr Macek a autorka této studie. Uměleckým ředitelem je v současné době Robert Hugo.

2 Jedná se zejména o tyto práce: HELFERT, Vladimír. Jiří Benda. Př̀spěvek k problému české hudebni emigrace, I. část (Základy), Brno 1929; TÝŽ. Jiři Benda. Př́spěvek k problému české hudebni emigrace, II. části 1. díl (Gota 17501774). Brno 1934; TÝŽ. Hudebni barok na českých zámcích. Jaroměřice za hraběte Jana Adama z Questenberku, Praha 1916; týž. Hudba na jaroměrickém zámku. František Míca 1696-1745, Praha 1924. O významu Helfertových spisů srv. mj. SLOUKA, Petr. ,Jaroměřické“ monografie Vladimíra Helferta jako vzor pro výzkum opery ve stř̌ední Evropě v první polovině 18. století. Musicologica Brunensia, 2015, roč. 50, č. 1, s. 87-100, a dále VOLEK, Tomislav. Mozart, die italienische Oper des 18. Jahrhunderts und das musikalische Leben im Königreich Böhmen. Mit der Don-Juan-Studie von Vladimír Helfert (eds. Milada Jonášová a Matthias Pernerstorfer), Wien: Hollitzer Verlag, 2016.

3 Dále i práce Slohové a ideové prvky barokni hudby (Brno 1934); Hudebni estetika v Descartesově Compendiu musicae (Praha 1945); hudebnímu baroku je věnována zvláštní kapitola v Rackově knize Česká hudba (Praha 1958). Rackovy výzkumy v oblasti staré hudby je ovšem v dnešní době nutno považovat za problematické. 
Vzhledem k tomu, že samotný inventář byl poté dlouho považován za ztracený, a rovněž vzhledem k mimořádnému významu tohoto pramene pro středoevropské baroko, staly se kopie Fukačovy diplomové práce součástí knihoven mnoha významných muzikologů z celé Evropy, včetně například velkého vivaldiovského badatele Michaela Talbota.

Hned v roce dokončení své diplomové práce, tedy v r. 1958, publikoval Fukač ve zkrácené formě výsledky svého výzkumu ve studii Hudba na Hradišti s podtitulem Př́ispěvek k problematice hudebního baroka. ${ }^{4} \mathrm{Z}$ pramenů vázaných na prostředí rodného Znojma publikoval v r. 1960 také článek $K$ dějinám hudebního dramatu ve Znojmě. ${ }^{5}$ Citoval v něm řadu jezuitských aktivit zachycených v pramenech ze 17. a 18. století a věnoval též pozornost představení serenaty císařského dvorního vicekapelníka Antonia Caldary, která se ve Znojmě hrála pro členy císařského hofštátu cestou z pražské korunovace v r. $1723 .{ }^{6} \mathrm{Fu}-$ kač ve své „znojemské“ studii zmiňuje také libreto k oratoriu Das Leyden und Sterben deß Heylands Jesu Christi, které bylo uvedeno v roce 1734 v kapucínském kostele ve Znojmě. Tento důležitý pramen k dějinám barokního oratoria na Moravě byl v r. 2012 představen v širším kulturněhistorickém kontextu ve studii, kterou napsala autorka tohoto příspěvku společně s Vladimírem Maňasem. ${ }^{7}$

Z dílčích informací uvedených v křižovnickém inventáři těžil Fukač v řadě dalších studií. V článku Archaische Tendenzen in der Prager Barockmusik um das Jahr 1700 z r. $1965^{8}$ se věnoval některým skladbám zkomponovaným v palestrinovském stylu, přičemž se zaměřil především na takřka neznámého skladatele Johanna Adama Besneckera. Ve studii Generálbasová cvičeni z druhé poloviny 17. stoleti z r. $1962^{9}$ se podrobněji zabýval jiným pramenem od křižovníků - opisem části učebnice generálbasu, jejímž autorem byl pravděpodobně olomoucký hudebník Samuel Zindl. Fukač srovnával tato cvičení s pracemi císařského varhaníka Alessandra Pogliettiho. Ve studii Zur Entwicklung der Generalbasskenntnis im Gebiete von Mähren ${ }^{10}$ napsané o několik let později - v r. 1968 pro zahraniční publikum účastníků brněnského kolokvia rozšířil kontext svého výzkumu o srovnání s Johannem Matthesonem.

Z Fukačovy diplomové práce vychází i jeho studie Die Oratorienaufführungen bei den Prager Kreuzherren mit dem roten Stern als Typ lokaler Musikfeste vydaná o mnoho let později - v r. 1994. ${ }^{11}$ Zde ovšem - jako v některých jiných pracích, o nichž bude ještě řeč - zmiňuje nejprve některé terminologické problémy týkající se pojmu „Barock“. Co se týče hudby

4 Podyji 1958, únor 1958, s. 27-32, 45-47, 57-59, 74-76, 90-92, 100-102, 125-128.

5 Vlastivědný věstnik moravský, 1960, roč. 15, s. 255-260.

6 Toto dílo zpracovala později jako diplomovou práci Irena VESELÁ pod názvem Gratulačni opera La concordia de' pianetti a jeji provedení ve Znojmě roku 1723. Ústav hudební vědy FF MU, Brno 2001. Diplomová práce na Filozofické fakultě Masarykovy univerzity v Brně na katedře Hudební vědy. Vedoucím této diplomové práce byl Jiří Fukač sám.

7 PERUTKOVÁ, Jana - MAŇAS, Vladimír. Pašijové oratorium ve Znojmě roku 1734 - přríspěvek k poznání hudebního života na Moravě. Opus musicum, 2012, roč. 44, č. 3, s. 6-13.

8 Sbornik prací filozofické fakulty brněnské univerzity, řada F9, 1965, roč. 14, s. 93-105.

9 Sbornik praci filozofické fakulty brněnské univerzity, řada F6, 1962, roč. 11, s. 21-30.

10 In Musica antiqua. Colloquium Brno 1968. Rudolf Pečman (ed.). Brno 1968, s. 116-122.

11 Sbornik prací filozofické fakulty brněnské univerzity, řada hudebněvědná, H29, 1994, roč. 43, s. 69-89. 
v Čechách, vymezuje se proti znovu a znovu se vynořujícím a zpracovávaným tématům, která označuje za hvězdné chvíle („Sternstunden“) pražského hudebního života: provedení Fuxovy opery Costanza e fortezza, pražská léta Gluckova a Mozartův vztah k Praze. ${ }^{12}$ Dále potvrzuje domněnku Vladimíra Helferta, kterou publikoval v prvním dílu své monografie o Bendovi, že křižovníci byli vedle jezuitů hlavními nositeli oratorních produkcí v Praze. Krátce zmiňuje i oratoria provozovaná u sv. Mikuláše na Malé Straně, kteréžto téma podrobně zpracoval až Václav Kapsa v př́spěvku předneseném na brněnském kolokviu v r. 2013 a publikovaném o rok později v časopisu Musicologica Brunensia. ${ }^{13}$ Fukač ve své studii také zmiňuje typ sepolker jakožto oratorií provozovaných ve Svatém týdnu u Božího hrobu. Tato problematika zůstala ne zcela dostatečně zpracována až do dnešní doby. $\mathrm{V}$ současné době se na brněnském Ústavu hudební vědy snažíme ve spolupráci $\mathrm{s}$ vídeňským Don Juan Archivem vytvořit databázi libret sepolker vzniklých v 1. polovině 18. století (do roku cca 1760), a to v širším kontextu Moravy, Horního Rakouska a Vídně, přičemž prameny z Čech nám slouží prozatím jako srovnávací materiál.

A konečně poslední Fukačovou studií věnovanou křižovníkům je práce z r. 1998 s názvem Pöltenberg, Wien und die Musikkultur der Prager Kreuzherren, věnovaná šedesátým narozeninám jednoho z Fukačových nejlepších přátel, Theophila Antonicka. ${ }^{14}$ Upozorňuje na vztah pražských křižovníků k Vídni, potažmo k chrámu sv. Karla Boromejského, jimiž se v rámci výzkumu tamních hudebních aktivit tehdejší oslavenec Antonicek zabýval. Publikování této studie v zahraničí způsobilo, že je hojněji citována, např. salzburským muzikologem Thomasem Hochradnerem v příspěvku předneseném na kolokviu 2013 a také - podobně jako v př́ípadě Kapsy - publikovaném v časopisu Musicologica Brunensia. ${ }^{15}$ Tak byly Fukačovy výzkumy znovu rozvíjeny, a to mimobrněnskými badateli.

Metodologickému zkoumání hudebních procesů v českých zemích v době baroka a některým terminologickým otázkám se Fukač věnoval několikrát. Ve studii Der tschechische Musikbarock und methodologische Probleme seines Studiums z r. $1968^{16}$ upozornil na to, že národnostní aspekt, který byl v české, ale i německé hudební vědě poměrně silně pěstován, je pro toto období nedůležitý, a zdůraznil skutečnost, že tato otázka způsobila v minulých desetiletích mnohá nedorozumění. Manko, které měla česká muzikologie ohledně skladatelů z českých zemí, kteří mluvili primárně německy nebo pocházeli z německojazyčných oblastí, se ostatně české muzikologii nepodařilo bezezbytku odstranit ani do současnosti. Daným obdobím se Fukač v této studii zabýval z hlediska terminologie, přičemž upozornil na význam prací Helfertových, Riemannových, Adlerových, a rovněž na výzkumy R. Haase, C. Sachse, E. Schencka, a F. Blumeho. Dále hudební

12 S tímto vymezením však nelze zcela souhlasit, nebot' všechny Fukačem zmíněné situace přinášejí v posledních desetiletích díky pokračujícím kvalitním výzkumům nové zásadní poznatky.

13 KAPSA, Václav. Die Musik in der St. Nikolauskirche auf der Prager Kleinseite in der ersten Hälfte des 18. Jahrhunderts. Musicologica Brunensia, 2014, roč. 49, č. 1, s. 189-209.

14 Př́spěvek byl publikován in Österreichische Musik - Musik in Österreich. Beiträge zur Musikgeschichte Mitteleuropas. Theophil Antonicek zum 60. Geburtstag. Elisabeth Th. Hilscher (ed.). Tutzing 1998, s. 171-177.

15 HOCHRADNER, Thomas. Von zaghaftem Nachhall: zur Rezeptionsgeschichte der Oratorien von Johann Joseph Fux. Musicologica Brunensia, 2014, roč. 49, č. 1, s. 121-135.

16 Sbornik prací filozofické fakulty brněnské univerzity, řada hudebněvědná, H3, 1968, roč. 17, s. 7-20. 
barok podrobil kritickému průzkumu z hlediska estetického a topografického, přičemž upozornil na diverzitu daného období. Tehdy většinový názor, který rovněž zastával - že totiž zdejší církevní hudba před rokem 1700 představuje pouhou nesmělou syntézu generálbasové praxe $\mathrm{s}$ jednoduchou homofonií a mnoha zastaralými elementy - musíme dnes považovat za př́liš zjednodušený. Souhlasit lze ale s jeho tvrzením, že kolem r. 1700 přichází v hudbě v českých zemích zřetelný zlom. Důvody k němu Fukač podrobně nerozpracoval, ovšem odpovědi přináší v posledních desetiletích např. některé výzkumy Václava Kapsy a dalších muzikologů. Fukačovo terminologicky precizní vymezení pojmu „Barock“ lze nalézt i ve stejnojmenném hesle napsaném pro Lexikon zur deutschen Musikkultur. ${ }^{17}$ Obdobného rázu jako Fukačova studie o českém hudebním baroku je jeho článek takřka o dvacet let mladší, nazvaný „Mähren in der Musikgeschichte“ als Problem z r. $1987 .{ }^{18}$ Fukač v něm apeloval na chápání Moravy v celé šiŕí, jako geografického, demografického, etnického, politicky historického a kulturně historického fenoménu. Připomenul význam prací Christiana d'Elverta a znovu zdůraznil, že je nutno odmítnout staré národnostní koncepty. Kladl důraz na charakter Moravy jako křižovatky a jako „průchozího“ regionu. Jako významnou trasu, prostřednictvím níž byly zprostředkovány důležité kulturní a tedy také hudební vlivy, určil osu ,jih-sever“, ne tedy v tehdejší době mnohdy populární a schematické „východ-západ“. Kladl také požadavek na interdisciplinární zkoumání, který v dnešní době opět nabývá na naléhavosti. $\mathrm{V}$ této studii také upozornil na projekt „Morava v dějinách hudby“, který později realizovala knižně autorská dvojice Jiří Sehnal - Jiří Vysloužil. Výše uvedené Fukač ještě více rozpracoval v př́íspěvku z r. 1993 Die städtische und ländliche Dimension der Musikkultur Mährens (und zum Teil Österreichisch-Schlesiens), jejíž název je parafrází na spis Ch. d'Elverta. ${ }^{19}$ Upozornil na nutnost zabývat se regionálními, interregionálními a transregionálními aspekty. Kladl správně důraz na vytvoření obrazu Moravu jako multinárodnostního, geograficky a kulturně otevřeného regionu. Slezsku se pak samostatně věnoval ve studii Schlesische Impulse in der Musikgeschichte der böhmischen Länder. ${ }^{20}$

Naposledy se Fukač k problematice baroka v českých zemích z hlediska terminologického a metodologického vrátil v př́spěvku Die „Barock-Länder“ Böhmen und Mähren und ihre allzu frühe Entdeckung, vydaném v Bonnu v r. 2002, tedy v roce jeho úmrtí. ${ }^{21}$ Upozornil v něm na tvrdohlavé použivání nejednoznačných hudebních pojmů, jako jsou např́ílad baroko, romantismus nebo realismus a označil je za pouhý líný kompromis, odvolávaje se na Carla Dahlhause. Zdůraznil, že na každou etapu je možné a nutné nahlížet i z mimohudebních hledisek a zohledňovat celkový umělecký styl, duchovní a sociální

17 Lexikon zur deutschen Musikkultur. Böhmen, Mähren, Sudetenschlesien, I. Band, München 2000, s. 137-143.

18 Österreichische Musikzeitschrift, 1987, roč. 42, č. 4, s. 159-166.

19 In Colloquium Stadt und Region als Schauplätze des Musikgeschehens, Brno 1993. Petr Macek (ed.). Brno 1998, s. 9-14.

20 In Musikkultur in Schlesien zur Zeit von Telemann und Dittersdorf: Berichte der musikwissenschaftlichen Konferenzen in Pszczyna, Pless und Opava, Troppau 1993. Sinzig 2001, s. 207-219.

21 In Probleme der Migration von Musik und Musikern in Europa im Zeitalter des Barock: 15. Arolser Barock-Festspiele 2000: Tagungsbericht in Zusammenarbeit mit dem Institut für deutsche Musikkultur im östlichen Europa, Bonn. Friedhelm Brusniak - Klaus-Peter Koch (eds.). Sinzing 2002, s. 99-106. 
hnutí, a v neposlední řadě také to, jak se tyto aspekty projevovaly v hudebním dění; volá tedy po co nejširší kontextualizaci hudby. Zmínil také patriotické tendence Dlabačovy, Němečkovy a rovněž známý anonymní článek, pocházející též pravděpodobně z pera $\mathrm{F}$. X. Němečka, který vyšel v Allgemeine Musikalische Zeitung v r. 1799 pod názvem Über den Zustand der Musik in Böhmen. Dále se opět zabýval pojmem barok, jak jej chápal Helfert, nově přitom ovšem zohlednil termín „ř́ršský styl“ (dnes spíše nazývaný jako „Kaiserstil“), jenž byl produktem Sedlmayerovým a Riedelovým. ${ }^{22}$ Tento termín ostatně dodnes není v dostatečné míře usouvztažněn na hudbu. Fukač v této své studii upozornil také na Nettlův spis Musikbarock in Böhmen und Mähren, který následoval záhy po Helfertových výzkumech (byl publikován 1927). Závěrem uvedl tezi, že Nejedlý a Helfert jakožto první muzikologové, kteří v evropském muzikologickém kontextu hovořili o hudebním baroku, byli dědicové optiky, jež v českých zemích fungovala více než sto let před nimi.

Dlabačovým Lexikonem ${ }^{23}$ se ostatně Fukač zabýval už mnohem dříve, a to v příspěvku Die Musiklexikographische Methode B. J. Dlabačs und ihre kunstgeschichtlichen Hintergründe z r. $1971 .{ }^{24}$ Provedl důslednou kvantifikaci hesel a zjistil, že z celkového počtu 4443 hesel se $65,7 \%$ týká hudby, což vysvětluje Dlabačovým přirozeným zájmem, vzděláním a povoláním. Zjistil rovněž, že 77,85 \% hesel se týká umělců z Čech, zatímco z Moravy pouhých $2,75 \%$, tj. 80 umělců, ze Slezska pak o něco málo více $(3,05 \%) .{ }^{25}$ Kladl si také patrně jako první muzikolog otázku věrohodnosti obsahu slovníku, přičemž upozornil na existenci některých skupin hesel, která byla zpracována na základě jednoho pramene malé vypovídající hodnoty (pocházela tedy z jednoho nepříliš věrohodného zdroje). ${ }^{26} \mathrm{~K}$ problematice Dlabačova Lexikonu se později vyjadřovala i Zdeňka Pilkováa ${ }^{7}$ a nejnověji Jana Franková. ${ }^{28}$ Analýze barokní hudby Fukač věnoval dva spíše marginální příspěvky Hudebni analýza, jeji problémy $a$ „stará hudba “29 a Helfert analytik, přičemž oba vyšly v r. $1987 .{ }^{30}$

V oblasti šlechtických kapel se Fukač muzikologicky projevil až v 90. letech a zaměřil se nikoli na heuristiku, které se v té době na Moravě věnoval především Jiří Sehnal a někteří další muzikologové. Uchopil tento fenomén spíše metodologicky a terminologicky,

22 Srv. SEDLMAYR, Hans. Die politische Bedeutung des deutschen Barock. Der „Reichsstil“. Epochen und Werke. Gesammelte Schriften zur Kunstgeschichte. 2. Bd. Wien-München 1960; dále RIEDEL, Friedrich Wilhelm. Der „Reichsstil“ in der deutschen Musikgeschichte des 18. Jahrhunderts. In Bericht über den Internationalen Musikwissenschaftlichen Kongress Kassel 1962. Georg Reichert - Martin Just (eds.). Kassel 1963, s. 34-36.

23 Allgemeines historisches Künstler-Lexikon für Böhmen und zum Theil auch für Mähren und Schlesien, Prag 1815.

24 Sbornik praci filosofické fakulty brněnské university, řada hudebněvědná, H6, 1971, roč. 20, s. 63-86.

25 Zbytek tvoří hesla o skladatelích mimo tyto tři země Koruny české (16,35 \%).

26 K tomu též Jana FRANKOVÁ ve své dizertační práci Život a dílo Josefa Kohouta (1734-1777) jako příklad migrace hudebníků v osvícenské Evropě, školitelky: Jana Perutková a Raphaëlle Legrand, MU Brno - Université Paris-Sorbonne 2015.

27 PILKOVÁ, Zdeňka. Zur Frage der Musiker aus böhmischen Ländern, die im Ausland wirkten, 1740-1810. In Telemanniana e talia musicologica: Festschrift für Günter Fleischhauer zum 65. Geburtstag. Dieter Gutknecht Günter Fleischhauer - Hartmut Krones - Frieder Zschoch (eds.). Ziethen 1995, s. 215-220.

28 Kromě uvedené dizertace tak Franková učinila ještě v příspěvku Mýtus české hudební emigrace z pohledu Dlabačova slovníku. Musicologica Brunensia, 2015, roč. 50, č. 1, s. 73-85.

29 Zpravodaj Společnosti pro starou hudbu, 1987, roč. 3, s. 11-19.

30 In Vladimír Helfert v českém a evropském kontextu. Rudolf Pečman (ed.). Brno 1987, s. 20-23. 
jak to měl ve zvyku ve svých pracích z 80. a 90. let, a to ve studii z r. 1992 Die Schloßkulturen als musikwissenschaftliches Thema.${ }^{31}$ Výrazný byl také jeho podíl na hesle zámecká hudebni kultura v Slovníku české hudební kultury, kde prezentoval mimo jiné teorii o údajně specifickém českém fenoménu symbiózy zámku a podzámčí. S Fukačovými závěry se vyrovnával Václav Kapsa v příspěvku předneseném na konferenci v Jaroměřicích nad Rokytnou nazvaném Šlechtické kapely $v$ českých zemich doby baroka: staré a nové otázky jejich zkoumáni ${ }^{32}$ Fukač je rovněž autor hesla Adelskapellen pro Lexikon zur deutschen Musikkultur. ${ }^{33}$

Dalším fenoménem, ke kterému se Fukač opakovaně vracel, byl Mannheim. První dvě jeho studie na toto téma pocházejí ze 70. let. V příspěvku z kolokvia z r. 1970 Biographische und quellenkundliche Gegebenheiten in der Musikgeschichte der böhmischen Länder in Beziehung zur Mannheimer Schule (Stand der Forschung) ${ }^{34}$ reaguje především na Eggebrechtův příspěvek Mannheimer Stil: Technik und Gehalt. ${ }^{35}$ Ve studii Mannheimská otázka po sedmdesáti letech ${ }^{36}$ publikované v časopisu Opus musicum se nejprve velmi případně vymezil proti mechanickému chápání dějin hudby jako evoluční řady, tj. napřríklad že po renesanci nastoupilo baroko, pak klasicismus atd. Postuloval zde také pravděpodobně jako vůbec první evropský muzikolog základní otázku, v jakém slova smyslu byla mannheimská škola kompoziční školou, resp. zda se nejednalo spíše o jistá primárně zvuková specifika daná především obsazením a velikostí mannheimského orchestru. Zaměřil se také na problematiku typizace a individuálních př́ínosů u skladatelů tohoto období. Určitou nevýhodou je to, že zde ještě nedostatečně sleduje migrační trasy jednotlivých skladatelů, kteří se uplatnili v Mannheimu. Zatímco ve studii publikované v časopisu Opus musicum kritizoval to, že správnému uchopení fenoménu mannheimské školy se věnuje jen malá pozornost, po necelých dvaceti letech se již situace zásadně změnila. Jeho příspěvek Böhmische Länder und Mannheim im Netzwerk von „Musiktrassen“ vyšel v r. 1993 ve sborníku nazvaném Untersuchungen zu Musikbeziehungen zwischen Mannheim, Böhmen und Mähren im späten 18. und frühen 19. Jahrhundert. ${ }^{37}$ Fenoménem „Mannheim“ se tedy zabývalo celé jednání symposia pořádaného hned třemi institucemi přímo v Mannheimu v r. 1987. ${ }^{38}$ Publikování této studie na mezinárodní půdě opět napomohlo recepci Fukačových výzkumů. ${ }^{39}$

31 In Studie Muzea Kroměřižska 91, Kroměříž-Brno 1992, s. 4-10.

32 Clavibus unitis, 2014, roč. 3, s. 177-182.

33 Lexikon zur deutschen Musikkultur. Böhmen, Mähren und Sudetenschlesien, Bd. 1, München 2000, s. 69-80.

34 In Colloquium Musica bohemica et europaea Brno 1970. Rudolf Pečman (ed.). Brno 1972, s. 219-233.

35 Tamtéž, s. 205-218.

36 Opus musicum, 1972, roč. 4, č. 8-9, s. 232-238; č. 10, s. 289-297.

37 Mainz-London-Madrid-New York-Paris-Tokyo 1993, s. 22-34.

38 Migrační trasy jsou též pojednány ve Fukačově studii s názvem K významu a historické úloze naší hudební emigrace 18. století v Rusku. In Svazky, vztahy, paralely. Ruská a česká hudba. Jiří Vysloužil (ed.). Brno 1973, s. $11-20$.

39 OTTENBERG, Hans-Günter. Dresden Instrumentalwerke böhmischer Komponisten in der Dresdner Hofmusik des 18. Jahrhunderts - Repertoireschwerpunkte, Stilistik, Überlieferungswege, Aufführungspraxis. In Musiker-Migration und Musik-Transfer zwischen Böhmen und Sachsen im 18. Jahrhundert. Bericht über das Interna- 
$\mathrm{K}$ výzkumu migračních tras se Fukač vrátil ještě $\mathrm{v}$ př́íspěvku z konference konané v r. 1997 v Olomouci nazvaném Zur Problematik der Migrationstrassen: Möglichkeiten der tschechischen Musikforschung. ${ }^{40}$ Jedním z cílů konference bylo vytvoření podmínek pro získání finanční podpory projektu zaměřeného na migraci. Fukač poukázal nejprve na to, že kooperace Brna se zahraničním muzikologickým prostorem probíhá již dlouhá léta. Jako tehdy již renomovaný odborník na terminologii upozornil na ošidnost módních slov, které nazval „eurotermíny“, např. termínu „cirkulace“, přičemž se u takto označovaného jevu může ve skutečnosti jednat jen o výměnu, přenos, vzájemné působení či zpětnou vazbu, ale stále ještě se nemusí jednat o cirkulaci (tu si Fukač správně dovedl představit např. v prostředí duchovních řádů). Navrhl několik témat ke komparativnímu zkoumání, modelově např. hudební život u minoritů kolem r. 1730 ve čtyřech zemích, nebo tři či čtyři migrační trasy, přičemž doporučil zapojení studentů v př́islušných zemích resp. na příslušných univerzitách prostřednictvím diplomových prací, které by reprezentovaly sondy do dané problematiky. $\mathrm{V}$ každém případě je pro stanovení zpočátku jednoduchého cíle. Varoval - a to je pro dnešní dobu obzvlášt poučné - před jakousi burzou nebo veletrhem nápadů, kdy každý přispěje takříkajíc svým zbožím, aniž by byla naplněna základní idea projektu. Současně žádal, aby jeho varování nebyla nepochopena: nechtěl tlumit žádnou iniciativu, ale vyjádřil (z dnešního hlediska velmi oprávněné) pochybnosti o možnosti realizovat naddimenzované projekty v krátkém čase systémem mozaiky.

Nyní však již k Fukačově rozsáhlému projektu týkajícímu se hudebních inventářù, který byl až donedávna zapomenut. Důležitost zkoumání inventářủ byla v prostředí brněnské univerzitní muzikologie vnímána již od dob Helfertových, i když on sám na toto téma nic nepublikoval. Z r. 1938 pochází studie Jana Racka Inventár hudebnin tovačovského zámku z konce 17 století, ${ }^{41}$ z r. 1953 pak studie Theodory Strakové Kvasický inventár $z$ r. $1757{ }^{42} \mathrm{v}$ r. 1957 pak Miroslav Krejčí obhájil na zdejší katedře diplomovou práci Inventár̆ hudebnin kostela sv. Jakuba v Brně z r. 1763 se zvläštním zřetelem k Peregrinu Gravanovi. Ve stejném roce publikoval J. Vanický krátký text Nad hudebnimi inventári z počátku 17. století. ${ }^{43}$ Moravské inventáře byly tak již od počátku lépe podchyceny než inventáře z Čech. ${ }^{44}$ Rok po Krejčího diplomové práci pak vznikla Fukačova diplomová práce o křižovnickém inventáři. Jak bylo ukázáno, těžil z ní v několika studiích prakticky až do konce 90 . let. Ale nedosti na tom: Fukač především pochopil, že inventáře jsou prameny mimořádné důležitosti. Ještě v r. 1958, tedy v roce, v němž vytvořil svou diplomovou práci, publikoval

tionale Symposium vom 7. bis 9. November 2008. Hans-Günter Ottenberg - Reiner Zimmermann (eds.). Dresden 2012, s. 83-102.

40 Musicologica Olomucensia IV, Acta Unviersitas Palackiane Olomucensis, Olomouc 1998, s. 47-49.

41 Musikologie, 1938, roč. 1, s. 45-68.

42 Časopis Moravského musea - Vědy společenské, 1953, roč. 38, s. 105-149.

43 Hudebni rozhledy, 1957, roč. 10, č. 14-15, s. 640-641.

44 O tom referovala Jana Spáčilová v příspěvku s názvem Czech Music Inventories before 1800: Historical and Methodological Outline, který přednesla na konferenci Musikalische Inventare - Music Inventories. International Conference Ẽ Workshop, 4.-6. 9. 2014 (Universität Bern). 
krátkou, leč obsahově velice hutnou studii Cenný dokument moravského hudebního baroka. ${ }^{45}$ Jedná se vlastně o nálezovou zprávu o rajhradském inventáři, včetně informací o repertoáru ad. O inventáři pak publikovala Theodora Straková rozsáhlejší studii až o patnáct let později, ${ }^{46}$ nové informace v tomto směru pak přináší dizertační práce brněnského doktoranda Pavla Žůrka. ${ }^{47}$

V r. 1966 ovšem Fukač publikoval rozsáhlou, více než šedesátistránkovou studii Tschechische Musikinventare: Zur Frage der komplexen Bearbeitung historischer Musikverzeichnisse. ${ }^{48}$ Zabýval se v ní metodologickou stránkou zkoumání inventářů a uvedl, že inventář představuje nejautentičtější obraz aktuálního repertoáru konkrétní lokality v určitém okamžiku hudebního vývoje, na rozdíl od hudebních sbírek, které procházely proměnami $\mathrm{v}$ čase a dnes jsou vesměs dochovány nekompletně. Jeho definice, kterou je dnes již možno považovat za kultovní a již publikoval v hesle Katalog v SČHK, zní: „Hudebni inventář jako specifický typ písemnosti úředni povahy, zpravidla administrativně-evidenčni funkce (jako výsledek inventarizace), představuji z hudebněhistorické perspektivy jeden z nejdůležitějšich typů pramenů. "49 Zmíněná studie z r. 1966 bohužel nebyla publikována v žádném pravidelně vycházejícím muzikologickém časopise, nýbrž v těžko dostupném sborníku. Přes svůj význam a zveřejnění v němčině proto zůstala nepovšimnuta, a to nejen v zahraničí, ale také u nás. Fukač ve studii také prezentoval metodiku, o níž se domníval, že je pro zpracování inventářů nejvhodnější. Navrhl kartotéční systém s co nejdůkladnějším zachycením relevantních položek, současně se ale - v roce 1966! - domníval, že nejlepší bude zpracování počítačové, až to vývoj počítačů umožní. Výsledkem Fukačova výzkumu ovšem nebyla pouze ona studie, ale práce, která udivuje svou soustavností a důkladností. Fukač se totiž v letech 1961-1965 nepokusil o nic menšího než o komplexní zpracování historických hudebních inventářů v celé ČR. Vytvořil tak dokumentaci, která zahrnuje 1165 stran. Karton s touto dokumentací je dnes uložen v ODH MZM (Cz-Bm), sign. G 8991. Má název České hudebni inventáře. Pokus o komplexni zpracováni hudebnich seznamů se zvláštnim žretelem ke stylovému profilu historických hudebnich sbirek české a moravské provenience, podtitul „B. Část dokumentační“ a vročení 1968. Hlavním přínosem této dokumentace je shromáždění pramenné základny, včetně informací z literatury pojednávající o nedochovaných inventářích. Kromě inventářů z Moravy, jejichž přehled přinesla částečně studie Jana Racka (zachycující 30 inventářů), ${ }^{50}$ zahrnul Fukač

45 Slovenská hudba, 1958, roč. 2, č. 4, s. 156-157.

46 Rajhradský hudebni inventář z roku 1725. Časopis Moravského muzea, 1973, roč. 58, s. 217-246. Ve stejné době vznikla také rozsáhlá studie Evy MIKANOVÉ s názvem Staroboleslavské hudební inventáře z 18 . a začátku 19. století. In Př́spěvky k dějinám české hudby I, Praha 1971, s. 7-66.

47 ŽU゚REK, Pavel. K větši slávě Boži i pro potěchu Múz. Podoby klášterni hudebni kultury v českých zemích 17. a 18. stoleti na přikladu benediktinů. Dizertační práce, školitel: Miloš Štědroň, Ústav hudební vědy FF MU, Brno 2017.

48 Tschechische Musikwissenschaft. Geschichtliches. Praha 1966, s. 1-64.

49 Heslo Katalog. In Slovnik české hudebni kultury Jiří Fukač - Jiří Vysloužil - Petr Macek (eds.). Praha 1997, s. 428-432. V rámci tohoto hesla navrhl Fukač typologii inventářů i podal jejich obsáhlý výčet (včetně charakteristik) v chronologickém záběru od konce 16. století do konce 19. století. Na toho heslo bezprostředně navázala studie Vladimíra MAŇASE K problematice hudebních inventářů: několik doplňujících poznámek k heslu Katalog Jiř́ího Fukače ve Slovníku české hudební kultury. Musicologica Brunensia, 2016, roč. 51, č. 2, s. 81-94.

50 RACEK, Jan. Hudební inventáře a jejich význam pro hudebněhistorické bádání. Časopis Moravského musea 
nově také inventáře z Čech a dospěl k počtu 250 inventářů z celé Č́R z 56 lokalit, přičemž asi 50 pochází z doby před rokem 1800. Každý inventář je pojednán ve speciální složce, řazení je chronologicko-lokální. Dokumentace je koncipována jako systém složený ze dvou komplementárních znakových soustav. První úroveň zachycuje vnější, formální stránku pramene, druhá obsahovou. Je to práce svým rozsahem i metodologií mimořádná a zdá se, že ve srovnatelné šíríi, v jaké Jiří Fukač pracoval s historickými inventáři českých zemí už od počátku šedesátých let 20. století, se mu s výjimkou Jiřího Sehnala dodnes nepřibližuje v evropském měřítku žádný jiný muzikolog. ${ }^{51}$ Přesto byla tato Fukačova práce zcela zapomenuta, znovuobjevila ji až Jana Spáčilová, která v době svého působení na pozici kurátora Oddělení dějin hudby Moravského zemského muzea zpracovala a zkatalogizovala zmíněný karton. ${ }^{52}$ Ujala se také představení Fukačova projektu na konferenci na univerzitě v Bernu v r. $2014 .{ }^{53} \mathrm{~K}$ tomu dlužno podotknout, že většina evropských zemí s výzkumem inventářů z různých důvodů teprve začíná, primát českých a především moravských muzikologů v této oblasti je tedy nezpochybnitelný. ${ }^{54}$

Jak již bylo řečeno, nezávisle na Fukačových výzkumech inventáře v posledních několika desetiletích zpracovával Jiří Sehnal, v poslední době na bádání v tomto směru řadou studií navazuje Vladimír Maňas. ${ }^{55} \mathrm{Na}$ našem brněnském Ústavu hudební vědy stavu byly v tomto směru rovněž zadávány některé diplomové práce. ${ }^{56}$ Znovuobjevení Fukačových

- Vědy společenské, 1962, roč. 47, s. 135-162.

51 SEHNAL, Jiří. Das älteste Musikalieninventar Mährens. Beiträge zur Musikwissenschaft, 1965, roč. 7, s. 139148. TÝŽ. Die Musikkapelle des Olmützer Bischofs Maximilian Hamilton (1761-1776). Die Musikforschung, 1971, roč. 24, s. 411-417. TÝŽ. Das Musikinventar des Olmützer Bischofs Leopold Egk aus dem Jahre 1760 als Quelle vorklassischer Instrumentalmusik. Archiv für Musikwissenschaft, 1972, roč. 29, č. 4, s. 285-317. TÝŽ. Nové příspěvky k dějinám hudby na Moravě v 17. a 18. století. Časopis Moravského musea - Vědy společenské, 1975, roč. 60 , s. 165-170. TÝŽ. Hudební inventář kostela v Moravské Třebové z konce třicetileté války. Hudebni věda, 2015 , roč. 52, č. 1 , s. 5-28.

52 Průklepová kopie je uložena v ODH MZM pod signaturou G 8991.

53 Viz pozn. 44. Srv. též SPÁČILOVÁ, Jana. Musikalische Inventare / Musical Inventories, Internationale Tagung / International Conference and Workshop, Universität Bern 4.-6. 9. 2014 [zpráva o konferenci]. Hudebni věda, 2014, roč. 51, č. 3-4, s. 417-419.

54 Výzkum inventářů je na vysoké úrovni i na Slovensku, částečně nesporně pod vlivem J. Sehnala, srv. Jana Kalinayová (ed.). Hudobné inventáre a repertoár viachlasnej hudby na Slovensku v 16.-17. storoči, Bratislava 1994. Na publikaci se dále podíleli Ladislav Kačic, jehož výzkumy inventářů jsou rovněž velmi významné pro středoevropský kontext, dále Ivana Korbačková a Janka Petöczová.

55 MAŇAS, Vladimír. Hudba v Moravské Ostravě do roku 1800. Magisterská diplomová práce, Ústav hudební vědy FF MU, vedoucí práce: Miloš Štedroň, Brno 2003. TÝŽ. Inventář hudebnin farního kostela v Novém Jičíně z roku 1630. Musicologica Brunensia, 2012, roč. 47, č. 2, s. 73-77. TÝŽ. Prostějovský inventář hudebnin z roku 1608. Opus musicum, 2014, roč. 48, č. 6, s. 6-29. TÝŽ. Dobový soupis motet Nicolause Zangia z roku 1608 a jeho souvislosti. Opus musicum, 2016, roč. 48, č. 2, s. 6-19. S problematikou inventářů vystoupil Maňas také na konferenci The Reception of Small-Scale Motet in Central and Eastern Europe v Padově v r. 2016, jeho př́spěvek měl název Italian repertoire in Moravia based on the oldest inventories up to ca1650. V českém prostředí patří k málu recentních studií HoRYNA, Martin: Inventář z roku 1608 jako svědectví o hudebním životě zlatokorunského kláštera. In Zlatá Koruna - dějiny, památky, lidé. České Budějovice: 2007, s. 389-399.

56 ČÍHAL, Petr. Moravské hudebni inventáře 1725-1781. Bakalářská diplomová práce, Ústav hudební vědy FF MU, vedoucí práce: Jana Perutková, Brno 2008. (TÝŽ později publikoval rovněž studii Hudební inventář jezuitů v Uherském Hradišti z roku 1730. In Slovácko: společenskovědni sbornik pro moravsko-slovenské pomezí. Ed. Ivo Frolec. Uherské Hradiště, 2012 [vyd. 2013], s. 225-242.) STANĚK, Jan. Inventář hudebnin piaristické koleje ve Slaném. Bakalářská diplomová práce, Ústav hudební vědy FF MU, vedoucí práce: Jana Perutková, Brno 2014. 
materiálů se stalo jedním ze zásadních impulzů pro zahájení rozsáhlejšího výzkumného projektu, pro nějž se podařilo získat podporu GA ČR, přičemž jedním z jeho hlavních cílů je aktualizování a doplnění Fukačova soupisu, nebot, jak konstatuje Vladimír Maňas, nález prakticky každého hudebního inventáře pozdního středověku a raného novověku může mít zásadní př́ínos, jelikož může výrazně proměnit naše dosavadní znalosti, a to nejen o dané lokalitě, ale i v širším kontextu. Proto je nutno pracovat s co nejrozsáhlejším souborem relevantních pramenů. Důležitá je také možnost konfrontace původních inventářu či majetkových soupisů s dochovanou sbírkou hudebnin či hudebních nástrojů, pokud existuje. Pomocí inventářů lze do určité míry sledovat proměny repertoáru i instrumentáře, změny $\mathrm{v}$ terminologii hudebních nástrojů i osudy hudebních sbírek a jednotlivých artefaktů. Právě korelace s dochovanou pramennou základnou a dosavadním stavem bádání může studium hudebních inventářu patřičně zhodnotit. ${ }^{57}$ Koncept naznačený Jiřím Fukačem v nedávné době rozpracovala na příkladu dvou českých klášterních sbírek nástrojů Tereza Žůrková, když se zabývala dochovanými hudebními nástroje z klášterů v Oseku a Strahově na základě dobových inventářů. ${ }^{58}$ Jana Spáčilová s Jiřím Kroupou zase vydali na základě Fukačova soupisu studii zabývající se inventáři chotkovské hudební sbírky. ${ }^{59}$

Předložená studie nemá být zcela vyčerpávajícím výčtem Fukačových textů věnovaných problematice tzv. staré hudby. Z výše uvedených faktů nicméně jasně vyplývá, že k oblasti hudby v Čechách i na Moravě v 18. století, k výzkumu problematiky a významu hudebního baroka v českých zemích a k migraci, především pak českých hudebníků ve druhé polovině 18. století, se Jiří Fukač vracel po celý svůj profesní život. Jeho pramenné výzkumy v oblasti starší hudby i metodologické podněty byly přínosné nejen v době publikování př́íslušných studií, ale jsou inspirativní i pro dnešek, a to nejen v republikovém měřítku, ale i v mezinárodním kontextu.

Studie vznikla v rámci projektu Grantové agentury České republiky Hudební inventáre raného novověku v českých zemích (GA16-17615S).

\footnotetext{
KRAMÁŘOVÁ, Helena: Chrámové inventâre hudebnin z přelomu 18. a 19. století. Hrabyňské inventáré. Bakalářská diplomová práce, Ústav hudební vědy FF MU, vedoucí práce: Vladimír Maňas, Brno 2013. (TÁŽ také autorkou studie Hrabiner Inventare und das Kirchenmusikleben am Ende des 18. und am Anfang des 19. Jahrhunderts in Hrabin. Musicologica Brunensia, 2016, roč. 51, č. 2, s. 53-68.) PAVLICA, Lukáš. Hudebni provoz chrámu sv. Petra a Pavla v Brně v 18. a raném 19. stoleti. Bakalářská diplomová práce, Ústav hudební vědy FF MU, vedoucí práce: Vladimír Maňas, Brno 2016.
}

57 K tomu srv. Maňasovu zmíněnou studii (viz pozn. 49).

58 BERDYCHOVÁ (= ŽŮRKOVÁ), Tereza. Unum Instrumentum antiquum cujus nomen ignoratur: Dochované hudební nástroje z klášterů v Oseku a Strahově na základě dobových inventářů. Opus musicum, 2014, roč. 46, č. 1, s. 57-73. Inventáři se tato badatelka zabývala i ve své dizertaci Výroba nátrubkových dechových nástroju $v$ českých zemich v 18. a 19. století se zaměrenim na lesni rohy, Ústav hudební vědy FF MU, školitel: Vladimír Maňas, Brno 2015.

59 †Jiří Fukač (k vydání připravili Jiří K. KROUPA a Jana SPÁČILOVÁ). Dochované inventáře chotkovské hudební sbírky na zámku Kačina. Chotkové a Kutnohorsko. Antiqua Cuthna 5-11, 2009-2015, s. 42-64. 


\section{Bibliography}

\section{Selected titles:}

BERDYCHOVÁ (= Žůrková), Tereza. Unum Instrumentum antiquum cujus nomen ignoratur: Dochované hudební nástroje z klášterů v Oseku a Strahově na základě dobových inventářů. Opus musicum, 2014, roč. 46, č. 1, s. 57-73.

ČÍHAL, Petr. Moravské hudebni inventáre 1725-1781. Bakalářská diplomová práce, Ústav hudební vědy FF MU, vedoucí práce: Jana Perutková, Brno 2008.

DLABAČ, Bohumír. Allgemeines historisches Künstler-Lexikon für Böhmen und zum Theil auch für Mähren und Schlesien. Prag 1815.

EGGEBRECHT, Hans Heinrich. Mannheimer Stil: Technik und Gehalt. In Colloquium Musica bohemica et europaea Brno 1970. Rudolf Pečman (ed.). Brno 1972, s. 219-233.

FRANKOVÁ, Jana. Život a dílo Josefa Kohouta (1734-1777) jako př̌klad migrace hudebniků v osvicenské Evropě. Dizertační práce, školitelka: Jana Perutková, MU Brno 2015.

FRANKOVÁ, Jana. Mýtus české hudební emigrace z pohledu Dlabačova slovníku. Musicologica Brunensia, 2015, roč. 50, č. 1, s. 73-85.

FUKAČ, Jiří. Křižovnický hudebni inventář I-II. Diplomová práce. Brno 1958.

FUKAČ, Jiří. Hudba na Hradišti. Př́íspěvek k problematice hudebního baroka. Podyji 1958, únor 1958, s. 27-32, 45-47, 57-59, 74-76, 90-92, 100-102, 125-128.

FUKAČ, Jiří. K dějinám hudebního dramatu ve Znojmě. Vlastivědný věstnik moravský, 1960, roč. 15 , s. 255-260.

FUKAČ, Jiří. Archaische Tendenzen in der Prager Barockmusik um das Jahr 1700. Sbornik praci filozofické fakulty brněnské univerzity, řada F9, 1965, roč. 14, s. 93-105.

FUKAČ, Jiří. Generálbasová cvičení z druhé poloviny 17. století. Sbornik prací filozofické fakulty brněnské univerzity, řada $\mathrm{F} 6,1962$, roč. 11, s. 21-30.

FUKAČ, Jiří. Zur Entwicklung der Generalbasskenntnis im Gebiete von Mähren. In Musica antiqua. Colloquium Brno 1968. Rudolf Pečman (ed.). Brno 1968, s. 116-122.

FUKAČ, Jiří. Die Oratorienaufführungen bei den Prager Kreuzherren mit dem roten Stern als Typ lokaler Musikfeste. Sbornik praci Filozofické fakulty brněnské univerzity, řada hudebněvědná, H29, 1994, roč. 43, s. 69-89.

FUKAČ, Jiří. Pöltenberg, Wien und die Musikkultur der Prager Kreuzherren. In Elisabeth Th. Hilscher (ed.). Österreichische Musik - Musik in Österreich. Beiträge zur Musikgeschichte Mitteleuropas. Theophil Antonicek zum 60. Geburtstag. Tutzing 1998, s. 171-177.

FUKAČ, Jiří. Der tschechische Musikbarock und methodologische Probleme seines Studiums. Sbornik praci filozofické fakulty brněnské univerzity, řada hudebněvědná, H3, 1968, roč. 17, s. 7-20.

FUKAČ, Jiří. Barock. Lexikon zur deutschen Musikkultur. Böhmen, Mähren, Sudetenschlesien, I. Band, München 2000, s. 137-143.

FUKAČ, Jiří. Mähren in der Musikgeschichte“ als Problem. Österreichische Musikzeitschrift, 1987, roč. 42 , č. 4, s. 159-166.

FUKAČ, Jiří. Die städtische und ländliche Dimension der Musikkultur Mährens (und zum Teil Österreichisch-Schlesiens). In Colloquium Stadt und Region als Schauplätze des Musikgeschehens, Brno 1993. Petr Macek (ed.). Brno 1998, s. 9-14.

FUKAČ, Jiř́. Schlesische Impulse in der Musikgeschichte der böhmischen Länder. In Musikkultur in 
Schlesien zur Zeit von Telemann und Dittersdorf: Berichte der musikwissenschaftlichen Konferenzen in Pszczyna, Pless und Opava, Troppau 1993. Sinzig 2001, s. 207-219.

FUKAC̆, Jiří. Die „Barock-Länder“ Böhmen und Mähren und ihre allzu frühe Entdeckung. In Probleme der Migration von Musik und Musikern in Europa im Zeitalter des Barock: 15. Arolser Barock-Festspiele 2000: Tagungsbericht in Zusammenarbeit mit dem Institut für deutsche Musikkultur im östlichen Europa, Bonn. Friedhelm Brusniak - Klaus-Peter Koch (eds.). Sinzing 2002, s. 99-106.

FUKAČ, Jiří. Die Musiklexikographische Methode B. J. Dlabačs und ihre kunstgeschichtlichen Hintergründe. Sbornik praci filosofické fakulty brněnské university, řada hudebněvědná, H6, 1971, roč. 20 , s. $63-86$.

FUKAČ, Jiří. Hudební analýza, její problémy a „stará hudba“. Zpravodaj Společnosti pro starou hudbu, 1987, roč. 3, s. 11-19.

FUKAČ, Jiří. Helfert analytik. In Vladimír Helfert v českém a evropském kontextu. Rudolf Pečman (ed.). Brno 1987, s. 20-23.

FUKAČ, Jiří. Die Schloßkulturen als musikwissenschaftliches Thema. In Studie Muzea Kroměřžska 91, Kroměříž-Brno 1992, s. 4-10.

FUKAČ, Jiří. Adelskapellen. Lexikon zur deutschen Musikkultur. Böhmen, Mähren und Sudetenschlesien, Bd. 1, München 2000, s. 69-80.

FUKAČ, Jiř́i. Biographische und quellenkundliche Gegebenheiten in der Musikgeschichte der böhmischen Länder in Beziehung zur Mannheimer Schule (Stand der Forschung). In Colloquium Musica bohemica et europaea Brno 1970. Rudolf Pečman (ed.). Brno 1972, s. 219-233.

FUKAČ, Jiří. Mannheimská otázka po sedmdesáti letech. Opus musicum, 1972, roč. 4, č. 8-9, s. 232-238; č. 10, s. 289-297.

FUKAČ, Jiří. Böhmische Länder und Mannheim im Netzwerk von „Musiktrassen“. Untersuchungen zu Musikbeziehungen zwischen Mannheim, Böhmen und Mähren im späten 18. und frühen 19. Jahrhundert. Mainz-London-Madrid-New York-Paris-Tokyo 1993, s. 22-34.

FUKAČ, Jiří. K významu a historické úloze naší hudební emigrace 18. století v Rusku. In Svazky, vztahy, paralely. Ruská a česká hudba. Jiří Vysloužil (ed.). Brno 1973, s. 11-20.

FUKAČ, Jiří. Zur Problematik der Migrationstrassen: Möglichkeiten der tschechischen Musikforschung. Musicologica Olomucensia IV, Acta Unviersitas Palackiane Olomucensis, Olomouc 1998, s. $47-49$.

FUKAČ, Jiří. Cenný dokument moravského hudebního baroka. Slovenská hudba, 1958, roč. 2, č. 4, s. $156-157$.

FUKAČ, Jiří. Tschechische Musikinventare: Zur Frage der komplexen Bearbeitung historischer Musikverzeichnisse. Tschechische Musikwissenschaft. Geschichtliches. Praha 1966, s. 1-64.

FUKAČ, Jiří. Katalog. In Slovnik české hudebni kultury. Jiří Fukač - Jiří Vysloužil - Petr Macek (eds.). Praha 1997, s. 428-432.

FUKAČ, Jiří. České hudebni inventáré. Pokus o komplexni zpracováni hudebnich seznamů se zvläštnim zřetelem ke stylovému profilu historických hudebnich sbirek české a moravské provenience, uloženo v ODH MZM, (Cz-Bm), sign. G 8991.

HELFERT, Vladimír. Jiři Benda. Př́spěvek k problému české hudebni emigrace, I. část (Základy), Brno 1929.

HELFERT, Vladimír. Jiři Benda. Příspěvek k problému české hudebni emigrace, II. části 1. dil (Gota 1750-1774). Brno 1934.

HELFERT, Vladimír. Hudebni barok na českých zámcích. Jaroměrice za hraběte Jana Adama z Questenberku. Praha 1916. 
HELFERT, Vladimír. Hudba na jaroměrickém zámku. František Míca 1696-1745. Praha 1924.

HOCHRADNER, Thomas. Von zaghaftem Nachhall: zur Rezeptionsgeschichte der Oratorien von Johann Joseph Fux. Musicologica Brunensia, 2014, roč. 49, č. 1, s. 121-135.

HORYNA, Martin. Inventář z roku 1608 jako svědectví o hudebním životě zlatokorunského kláštera. In Zlatá Koruna - dějiny, památky, lidé. České Budějovice: 2007, s. 389-399.

KAPSA, Václav. Die Musik in der St. Nikolauskirche auf der Prager Kleinseite in der ersten Hälfte des 18. Jahrhunderts. Musicologica Brunensia, 2014, roč. 49, č. 1, s. 189-209.

KAPSA, Václav. Šlechtické kapely v českých zemích doby baroka: staré a nové otázky jejich zkoumání. Clavibus unitis, 2014, roč. 3, s. 177-182.

KALINAYOVÁ, Jana (ed.). Hudobné inventáre a repertoár viachlasnej hudby na Slovensku v 16.-17. storočí. Bratislava 1994.

KRAMÁŘOVÁ, Helena. Chrámové inventáře hudebnin z přelomu 18. a 19. století. Hrabyñské inventáře. Bakalářská diplomová práce, Ústav hudební vědy FF MU, vedoucí práce: Vladimír Maňas, Brno 2013.

KRAMÁŘOVÁ, Helena. Hrabiner Inventare und das Kirchenmusikleben am Ende des 18. und am Anfang des 19. Jahrhunderts in Hrabin. Musicologica Brunensia, 2016, roč. 51, č. 2, s. 53-68.

KREJČÍ, Miroslav. Inventář hudebnin kostela sv. Jakuba v Brně z r. 1763 se zvláštním zřetelem k Peregrinu Gravanovi. Diplomová práce, Brno 1967.

KROUPA, Jiří K. - SPÁČILOVÁ, Jana (eds.). †Jiří Fukač. Dochované inventáře chotkovské hudební sbírky na zámku Kačina. Chotkové a Kutnohorsko. Antiqua Cuthna 5-11, 2009-2015, s. 42-64.

MAŇAS, Vladimír. K problematice hudebních inventářů: několik doplňujících poznámek k heslu Katalog Jiřího Fukače ve Slovníku české hudební kultury. Musicologica Brunensia, 2016, roč. 51, č. 2, s. 81-94.

MAŇAS, Vladimír. Hudba v Moravské Ostravě do roku 1800. Magisterská diplomová práce, Ústav hudební vědy FF MU, vedoucí práce: Miloš Štedroň, Brno 2003.

MAŇAS, Vladimír. Inventář hudebnin farního kostela v Novém Jičíně z roku 1630. Musicologica Brunensia, 2012, roč. 47, č. 2, s. 73-77.

MAŇAS, Vladimír. Prostějovský inventář hudebnin z roku 1608. Opus musicum, 2014, roč. 48, č. 6 , s. 6-29.

MAŇAS, Vladimír. Dobový soupis motet Nicolause Zangia z roku 1608 a jeho souvislosti. Opus musicum, 2016, roč. 48, č. 2, s. 6-19.

MIKANOVÁ, Eva. Staroboleslavské hudební inventáře z 18. a začátku 19. století. In Př́spě̃uky $k$ dějinám české hudby I, Praha 1971, s. 7-66.

OTTENBERG, Hans-Günter. Dresden Instrumentalwerke böhmischer Komponisten in der Dresdner Hofmusik des 18. Jahrhunderts - Repertoireschwerpunkte, Stilistik, Überlieferungswege, Aufführungspraxis. In Musiker-Migration und Musik-Transfer zwischen Böhmen und Sachsen im 18. Jahrhundert. Bericht über das Internationale Symposium vom 7. bis 9. November 2008. Hans-Günter Ottenberg - Reiner Zimmermann (eds.). Dresden 2012, s. 83-102.

PAVLICA, Lukáš. Hudebni provoz chrámu sv. Petra a Pavla v Brněv 18. a raném 19. století. Bakalářská diplomová práce, Ústav hudební vědy FF MU, vedoucí práce: Vladimír Maňas, Brno 2016.

PERUTKOVÁ, Jana - MAŇAS, Vladimír. Pašijové oratorium ve Znojmě roku 1734 - příspěvek k poznání hudebního života na Moravě. Opus musicum, 2012, roč. 44, č. 3, s. 6-13.

PILKOVÁ, Zdeňka. Zur Frage der Musiker aus böhmischen Ländern, die im Ausland wirkten, 1740-1810. In Telemanniana e talia musicologica: Festschrift für Günter Fleischhauer zum 65. Geburtstag. Dieter Gutknecht - Günter Fleischhauer - Hartmut Krones - Frieder Zschoch (eds.). Ziethen 1995, s. $215-220$. 
RACEK, Jan. Inventář hudebnin tovačovského zámku z konce 17 století. Musikologie, 1938, roč. 1, s. $45-68$.

RACEK, Jan. Hudební inventáře a jejich význam pro hudebněhistorické bádání. Časopis Moravského musea - Vědy společenské, 1962, roč. 47, s. 135-162.

SEHNAL, Jiří. Das älteste Musikalieninventar Mährens. Beiträge zur Musikwissenschaft, 1965, roč. 7, s. 139-148.

SEHNAL, Jiří. Die Musikkapelle des Olmützer Bischofs Maximilian Hamilton (1761-1776). Die Musikforschung, 1971, roč. 24, s. 411-417.

SEHNAL, Jiř́i. Das Musikinventar des Olmützer Bischofs Leopold Egk aus dem Jahre 1760 als Quelle vorklassischer Instrumentalmusik. Archiv für Musikwissenschaft, 1972, roč. 29, č. 4, s. 285-317. Sehnal, Jiří. Nové příspěvky k dějinám hudby na Moravě v 17. a 18. století. Časopis Moravského musea - Vědy společenské, 1975, roč. 60, s. 165-170.

SEHNAL, Jiří. Hudební inventář kostela v Moravské Třebové z konce třicetileté války. Hudebni věda, 2015, roč. 52, č. 1, s. 5-28.

SLOUKA, Petr. ,Jaroměřické“ monografie Vladimíra Helferta jako vzor pro výzkum opery ve střední Evropě v první polovině 18. století. Musicologica Brunensia, 2015, roč. 50, č. 1, s. 87-100.

STANĚK, Jan. Inventář hudebnin piaristické koleje ve Slaném. Bakalářská diplomová práce, Ústav hudební vědy FF MU, vedoucí práce: Jana Perutková, Brno 2014.

STRAKOVÁ, Theodora. Kvasický inventář z r. 1757. Časopis Moravského musea - Védy společenské, 1953, roč. 38, s. 105-149.

STRAKOVÁ, Theodora. Rajhradský hudební inventář z roku 1725. Časopis Morauského muzea, 1973, roč. 58, s. 217-246.

VESELÁ, Irena. Gratulačni opera La concordia de' pianetti a její provedeni ve Znojmě roku 1723. Ústav hudební vědy FF MU, Brno 2001. Diplomová práce na Filozofické fakultě Masarykovy univerzity v Brně na katedře Hudební vědy. Vedoucí práce Jiří Fukač.

VOLEK, Tomislav. Mozart, die italienische Oper des 18. Jahrhunderts und das musikalische Leben im Königreich Böhmen. Mit der Don-Juan-Studie von Vladimír Helfert (eds. Milada Jonášová a Matthias Pernerstorfer), Wien: Hollitzer Verlag, 2016.

ŽU゚REK, Pavel. K větši slávě Boži i pro potěchu Múz. Podoby kläšterni hudebni kultury v českých zemích 17. a 18. stoleti na přkladu benediktinů. Dizertační práce, školitel: Miloš Štědroň, Ústav hudební vědy FF MU, Brno 2017.

ŽŮRKOVÁ, Tereza. Výroba nátrubkových dechových nástrojů v českých zemích v 18. a 19. století se zaměřnim na lesni rohy. Dizertační práce, školitel: Vladimír Maňas, Ústav hudební vědy FF MU Brno 2015. 
